\title{
Annexin A2
}

National Cancer Institute

\section{Source}

National Cancer Institute. Annexin A2. NCI Thesaurus. Code C105378.

Annexin A2 (339 aa, $\sim 39 \mathrm{kDa}$ ) is encoded by the human ANXA2 gene. This protein is involved in lig and binding, signal transduction and bone development. 